\title{
Emotion and Agency within NGO Development Education: what is at work and what is at stake in the classroom?
}

Rachel Tallon

Victoria University of Wellington, (New Zealand)

\begin{abstract}
There have been concerns that development education is losing its radical heritage as it becomes populated by educational material produced by non-governmental organisations (NGOs). This paper looks at two interlinked aspects of NGO material, the use of emotion to encourage social action, and the centrality of the Northern student as part of that action. Empirical research is used to illustrate how these two aspects can arise when a traditional development framework is used when teaching about global inequalities and social justice in the New Zealand context. If these interlinked aspects are embedded in the formal learning of the classroom, there are possible learning outcomes that are not intended. The paper discusses how the mix of emotion and agency is affected by the relations of power that exist in a classroom. Learning about global inequalities in the classroom has been discussed in the literature, but with little reference to student voice. This paper seeks to add to the discussion concerning the place and influence of NGO material in schools and how learning about the distant Other is affected by this.
\end{abstract}

Key words: Global South, NGOs, development education, emotions, social sciences

\section{Introduction}

In many countries, the international aid and development sector has an established presence in the formal classroom, both in terms of providing educational resources and through general campaigns (Arnold, 1988). This paper uses empirical research to further the discussion around two distinct but related issues concerning development education material provided by Northern-based non-governmental international aid agencies (NGOs). The first concerns the complications that can arise when social action (towards the South) becomes a semi-obligatory element of the classroom and emotion is employed to achieve this, and the second concerns the agency and centrality of the student in relationship with the distant Other $^{1}$ that is 
part of this social action. The discussion begins by outlining concerns in the literature around development education losing its radical political heritage and with this, the rising dominance of a traditional development framework. Findings from my own research are presented and discussed, followed by some observations and concluding comments that add to the discussion concerning the place and influence of NGO material within schools.

\section{Development education: the concern over perspective}

NGO education resource material on global development issues has come under scrutiny since Arnold first raised concerns about how the global South was represented, highlighting that such material was not apolitical (Andreotti, 2006; Arnold, 1988; Osler, 1994; Smith, 2004). NGO education material sits within the sphere of development education which began in the 1980s as a radical project, inspired by, among others, education theorist and critic Paulo Freire, that challenged dominant ways of thinking about development (Bourn, 2011). But as Bourn and Bryan point out, this radicalness has become diluted over the years as NGOs have themselves become part of larger systems that need to maintain a crucial funding and branding base (Bourn, 2011; Bryan, 2011). Bourn notes three distinctive and common aspects of development education: a charitable and development perspective towards the global South; an intercultural perspective that stresses diversity and exchange; and finally, a critical outlook that challenges ways of thinking about development (ibid: 20). Critiques of the changes in development education since its origins are concerned with growth in the first two perspectives, largely driven by NGOs that portray a more traditional perspective of development to their constituencies.

A review of educational material in Europe noted that much of the practice supports the agendas of NGOs or the government, with an emphasis on action (Rajacic, Surian, Fricke, Krause, and Davis, 2010). It is salient to point out here that NGOs are not a homogenous group of enterprises, they reflect all forms of social justice concerns and so their education material is varied in intent, style and usage. Whilst some ascribe to a form of development that highlights charity, others may take a more critical or wider perspective. Andreotti (2006) divided the sector into those with a 'soft' approach which emphasised compassion and the need for humanitarian assistance; and those with a more 'radical' or critical approach, which included postcolonial or other approaches which challenged the terms of 'development', and questioned the Eurocentric framework. A key dilemma for the sector is whether their material supports their organisation's agenda (and also raises its profile positively) or supports the wider educational aim of learning about structural inequality and injustice, which may include a critical approach to aid and development.

NGO educational material has come under critique as being narrow in scope, Eurocentric and a kind of 'Band-Aid' pedagogical response to complex issues of global injustice (see Andreotti, 2007; Bryan, 2011; Smith, 2004). After evaluating how the 
global South was taught in Irish schools, Bryan and Bracken (2011:15) were particularly concerned about the effects of a 'fundraising, fasting and having fun' approach that was common in some NGO material. Smith (2008:10) notes that in the United Kingdom, teachers raised concerns about NGOs' educative role in classrooms, leading some teachers to question the pedagogy of a 'charities mould' in which fundraising sneaks in as part of a focus on 'citizenship' or 'social justice' that may be occurring in the school setting. There is a difficulty facing NGO educators, in that whilst they may seek to challenge systemic structures that promote inequality, for many of them, funding demands and other institutional needs constrain them to remain within the more traditional (some would argue, neo-colonial) ways of viewing the world (see den Heyer, 2009; Jefferess, 2008, for further discussion). Sinclair (1994) states that many NGOs involved in development education have challenged the traditional modernistic view of development, and have tried to broaden ideas around what constitutes global development. In New Zealand, the same challenges have existed, with many NGO education staff keen to engage in critical thinking about their work. Although there is no formal analysis of the New Zealand development education situation, Diprose (2003) found that concerning representational practices, many NGOs practise more participatory forms of development in the field, but retain a traditional framing of development in their marketing to the New Zealand public.

Smith and Yanacopulos argue that the charity as development and disaster relief framework is the most contentious element of NGO marketing, but also its most persuasive and effective (Smith and Yanacopulos, 2004). It is 'what draws the crowds in' and is also a way for many in the South to use the NGO marketing apparatus to highlight their need and raise funds. Critics may argue that an NGO's charitable frame on development may accentuate the 'them versus us' binary and may 'closedown' knowledge about what constitutes development, rather than open it up (Andreotti, 2006; Marshall, 2005; Sinclair, 1994), but they may under appreciate the main attraction of such material: the opportunity to take action, the ethical pull to assist.

\section{The ethical call to be a good citizen}

Positioned within much of NGO education material is this key element of the opportunity to assist or to change one's own behaviour as an act of social justice. As Bryan (2011) notes, those within a traditional framework promote action that is often about an individual or collective's ability to raise awareness or money for a particular cause in an NGO's portfolio. Jefferess and Andreotti have critiqued this pedagogy as focussing on the deficit of the South, with the emphasis on the North being in a superior position to assist (Andreotti, 2010; Jefferess, 2008). They argue that the unequal relationship that is established continues a colonial framing of the world. The student in the North is placed in a superior position, with the invitation, 
and sometimes an implied onus, to assist in some manner: 'we learn about you, and then we help you'. As Lambert and Morgan comment, the imperative can be on the student to adopt a stance, to carry out an activity, to change their behaviour in some manner, to make a difference (Lambert and Morgan, 2011:25). Biccum (2007:1114) also warns against producing "little developers' imbued with a capability that they should go out and do the developing'. If action is privileged over theory and critique then, as Standish argues, the curriculum may lose its objectivity. It becomes a means by which a certain agenda influences the way we think about the Other:

...by focusing on the support work of NGOs the [development] lessons reinforce the notion that developing countries are dependent upon Western intergovernmental organisations and NGOs and unable to shape their own futures. (Standish, 2009:140)

The two key areas this paper is concerned with, the use of emotion and the centrality of the student in the relationship with the global South, are interlinked and an integral part of social action being present in the classroom.

\section{The first aspect: the use of altruistic emotions}

Where social action towards the distant Other in the global South is an obligatory, but not compulsory part of the educational requirements, there can be emotional demands placed on students. These include feeling bad about not being able to feel certain expected emotions. It is possible that there is a significant range in how a 'semi-obligatory' call to action is received by students. This intentional employment of emotions to shift students into a frame of mind to accept the challenge of social action for the distant Other is difficult to measure and evaluate. How do we teach students to feel and to want to take action, and how do we measure the outcomes of this teaching and emotive work?

The mapping of emotions within education is both exploratory and multidisciplinary (Anderson and Smith, 2001; Davidson and Milligan, 2004; Kenway and Youdell, 2011). Boler (1999) identifies that emotions are a key site for control within the social sciences classroom, particularly altruistic emotions such as pity, compassion, empathy and even guilt. She describes how empathy is seen as a key component of emotional literacy and some see it as a requisite for social justice (ibid: 156). She asks who benefits from the production of empathy when it is used to bridge difference between us and the Other and she is not convinced that empathy leads to social justice or a shift in power relations. In her analysis of the agency of empathy she argues that a type of 'passive empathy' seeks an emotional reaction but absolves the reader of reflection or responsibility through the denial of power relations (ibid: 164). To rephrase her: passive empathy can allow 'familiarity', 'insight', 'knowledge' of the Other, but also a cathartic, innocent, vaguely voyeuristic sense of 'closure' (ibid:169).

This passiveness does not really shift the viewer into a zone of discomfort that they cannot control and do not welcome. Rather, it offers a simplistic view of the Other's 
misery and the format of learning is that of a type of judgement, followed by consolation (Taylor, 2011). Boler asks a wider political question: does the Other want our empathy or justice (ibid:157)? Critics have raised concerns about when a moral imperative to assist (or improve the Other) is present within a subject. Standish (2009) has argued that there is real danger for subjects, especially the social sciences, to become verbs; a student does not just learn geography, they do it. In examining this aspect of pedagogy, the semi-obligatory call to action, several interacting elements are able to be identified and described as they occur in the context of the classroom.

\section{Ethical hegemony, audience homogeneity and empathy}

The first element is the ethical hegemony that comes with the traditional development discourse vis-á-vis the NGO material. It is generally not up for question that the activities suggested by the NGO are not the most appropriate, nor that action is required. The desired social action is often designed around the consumer, the Northern student. It fits in with their timetable and the curriculum and is userfriendly for the teacher and the classroom setting (see Pykett, Cloke, Barnett, Clarke, and Malpass, 2010 for a discussion on how fair trade situates itself in the classroom). It is not designed to be a sacrifice that is unbearable or without results. The implication is that we can and that we should, and here are some options. Several emotions are called upon: pity, compassion, a sense of duty and often guilt, that we are more fortunate and we experience a horrible feeling of powerlessness in the face of evil. The consolation is to do something. This can have the effect of placing the student into a possible 'saviour role', moving from reflection through to action quickly, to salve any forms of guilt or apathy that may or may not have surfaced.

The second element is the assumed homogeneity of the student audience, that they are in a position to assist, and are culturally distant from the Other. It is often implied that there is little in common between 'them' and 'us' (Smith, 1999). Identification with the Other in the text is liable to cause a disruption: seeing one's own culture as distant, needy, and in some cases as an issue or a problem, may cause some students to reflect on whose reality and viewpoint is being expressed. Students, even of similar age, are rarely homogenous, they have diverse personalities, dispositions and cultural epistemologies that they each bring to the classroom, and none of these are necessarily stable. Some students are inclined to be more altruistic in nature, others less so, while some are inclined to question more. Students from the South in Northern classrooms may have mixed responses to NGO material.

The third element involves the intention and assumption that the students should feel a certain way (empathetic) and that as a natural consequence, they will be willing to take action as part of this feeling. Lindquist (2004) raises the same concerns as Boler concerning the control of emotions in the classroom. In an analogy 
with television talk shows, there is often the 'money shot' which pulls in the desired emotion, and NGO messaging can be specifically designed to manufacture certain emotions (Lindquist, 2004:195; Manzo, 2006). When learning of the Other's misfortune, there may be a danger in that certain emotional outcomes are not only expected, they are routinely produced and regulated so that they lead to a certain course of action (Joffe, 2008; Lidchi, 1993). At certain moments we are made aware of and then feel for the Other's misfortune; at other times, we do not. Students learn that one campaign will follow another. Other feelings, such as guilt, (and anger at being made to feel guilty), distrust, selfishness, apathy, boredom or cynicism are not entertained nor explored; they are by implication negative, as they disrupt the flow of the NGO directive, which takes us back to the first element.

These three elements (and there may be more besides) work continuously in public spaces, where the autonomous reader can change the channel, turn the page and activate their own response to the appeal, and research into this complex area is arguably incomplete (Cohen, 2001; Radley and Kennedy, 1995; Seu, 2010). Within the classroom setting, the student is less autonomous and NGO material, if it follows a charitable 'soft' approach towards development education, may have a strong ethical imperative, which students may not be encouraged to disagree with openly. The relations of power within the classroom may disadvantage young people; they may have oppositional thoughts and emotions but there may not be the space to voice them.

\section{The second aspect: the centrality of the student}

Sharon Todd's work exploring relations to the Other is one lens for understanding how we view the Other, particularly the poor or vulnerable (Todd, 2003). As with Boler, she challenges whether or not emotions are generated authentically and what exactly they achieve. Students may feel pressured to displace their own feelings to be able to take on feelings of compassion or even guilt that they are 'lucky' or 'blessed'. Todd argues that the learning that often takes place is about 'imagining how I would deal with this [situation of poverty or disaster etc.]'. Thus the empathy generated serves our own interests. It is constructed for self-reflection; it is not about respecting the difference of the Other (ibid:62). The radical and disruptive voice of the Other, their thoughts, opinions, anger or accusations is silent, unless mediated through the NGO. The educational goal is to imagine the suffering of the Other, but the actual thoughts, desires or actions of the Other are not really part of the equation. The Other's suffering becomes a tool for our own learning, our own development. This 'sculpting of the Other' is one in which postcolonial theorist Gayatri Spivak argues that the centre is not moved, the Subaltern remains at the periphery: [She] does not speak (as discussed in Andreotti, 2007). She becomes the poster child, the image that we can gaze upon.

10 International Journal of Development Education and Global Learning 4(2) 2012 
In the literature from disciplines such as visual culture and media studies there are concerns in how audiences are being positioned in their relationship to the distant Other. There has been extensive comment on audience reception (and negotiation) of the NGO-constructed relationship and appeal (Dalton, Madden, Chamberlain, Carr, and Lyons, 2008; Hibbert, Smith, Davies, and Ireland, 2007; Moeller, 1999; Paech, 2004; Seu, 2010; Smith, 2008). Much of the literature is around general audience reception and indeed, with vested interests, NGOs themselves have carried out valuable work in this area (DFID, 2002; VSO, 2002).

Media commentators have noted that NGOs in their marketing have moved away from the traditional 'guilt appeals' of previous decades to align themselves more with directives that stress the moral agency of the audience (Chouliaraki, 2011; Jefferess, 2012; Vestergaard, 2008). This shift in marketing focuses the message on the Northern actor: it is less about the Other or their demands, it is about what you can do. Chouliaraki argues that this form of marketing further accentuates the distance between the audience and the vulnerable Other, bringing in a new 'posthumanitarian age' whereby the voice of the Other is further marginalised through controlled media texts (Chouliaraki, 2011:365). The question is whether NGO educational material has also refocused its attentions towards the student as actor, creating a space and suitable mechanisms for the Northern student to act morally, at the risk of (unintentionally) increasing the distance.

This move away from emotive appeals and more to the centrality and power of the Northern actor to act, is part of the individualism of philanthropy that has many critics concerned (Boltanski, 1999; Chouliaraki, 2010, 2011; Cohen, 2001; Silverstone, 2007). Chouliaraki posits that solidarity becomes what we do together for them. We fundraise, we raise awareness and carry out good works that maintain the distance, so that we can help them, and as a side effect (hopefully) we become better people. Bryan argues that instead of challenging neoliberal political culture that supports this passive form of individual charity, NGOs can reflect it and even support it:

Moreover, the co-optation of radical projects and discourses by powerful actors, and the subsequent muting of their transformative potential, is one of the hallmark strategies of neoliberalism (Bryan, 2011:2).

Biccum (2005) makes the point that rather than challenging the colonial and development discourse, both government and non-government aid programmes can enforce it. This is done often by constructing poverty as a threat and something to be rid of, rather than focusing on greed or government policy that is protectionist in nature. As Kapoor (2004) notes, it is often easier to examine 'over there' and find fault, rather than to scrutinise 'over here'. These commentators reiterate the concern that Bryan (2011) has regarding the 'de-radicalising' of the sector.' 
The New Zealand political context is not dissimilar to that of the UK. Small (1997) was concerned about the arrival of large international NGOs into New Zealand in the 1990s that would focus on individual philanthropy and charity as the key means of poverty reduction. Within New Zealand, the main alternative to NGO education material for schools has historically come from a government-funded education resource centre, Global Focus Aotearoa ${ }^{2}$ (Small, 1997). Aligning itself with a postcolonial approach to development education, through its educational arm, the Global Education Centre, it offered a more critical perspective to development or global education (Beals, 2009). It was not tied to a fundraising agenda and was free, to some extent, to critique ideas around development and aid. The political landscape of overseas aid has undergone significant restructuring since the late 1990s (Overton, 2009) and recent changes ${ }^{3}$ in central government policy resulted in the closure of Global Focus Aotearoa in 2011.

This has meant that NGOs, funded largely through private donations are a significant element in the education resource market on issues concerning the global South in New Zealand. Many struggle to critique the very industry and paradigm that they are part of. This can lead to a pedagogy that intersperses knowledge with aid. This paper is concerned with the two interlinked issues of emotion and student centrality and how they manifest themselves in the reality of the classroom. Observations from empirical research are discussed to illustrate this.

\section{Observations from the field}

The research that this paper draws upon is within the New Zealand context. As part of a doctorate in development studies, field research carried out in 2011-12 involved working with six teachers and their year $10^{4}$ social studies students in five postprimary schools in New Zealand. The New Zealand Curriculum document (Ministry of Education, 2007), begins by outlining the vision, principles and values of the national curriculum. The curriculum includes specific achievement objectives which indicate various components of the subject that the students should be learning about. Within the learning area of the social sciences ${ }^{5}$, at levels three to five, (the equivalent of years eight to ten in the UK system) the subject is known as social studies and is compulsory. The guideline for the learning area is as follows:

In the social sciences, students explore how societies work and how they themselves can participate and take action as critical, informed and responsible citizens. (Ministry of Education, 2007: 17)

In social studies many of the achievement objectives can apply to issues of global inequality or issues around human rights and people responding to challenges that may face them. For example, the ninth achievement objective for level five states that 'Students should gain knowledge, skills and experience to understand how people define and seek human rights'. There are no specific directives for contexts, 
so teachers choose contexts based on resource availability, personal knowledge and student interest.

The central research question was around what meanings students make from NGO images and messages concerning development and the global South. A secondary question asked how the teacher used (if at all) NGO material in the classroom. For each school, there were three data collection activities for each year 10 class involved: the first involved each student answering a four page questionnaire about images, the terms associated with development and the impressions gained from learning about the global South. The second activity was a voice-recorded focus group. For this activity the students chose their own groups (of between two and four people) and answered further open-ended questions around development and a selection of generic NGO-style images ${ }^{6}$. For both activities the students were reminded that there were no right or wrong answers, it was their opinions that were important. They also remained anonymous throughout the research process and the teacher was away from the classroom for both activities. Following these, a few weeks later, there was a forty minute semi-structured interview with the teacher to gain their perspective on the use of NGO material and the teaching of Southern contexts. The teacher was sent aggregated comments from the student activities and a 'first impressions analysis' prior to the interview.

\section{Encouraging action: employing empathy}

For this paper, observations from one classroom will be drawn upon. In this classroom the teacher had used material by World Vision New Zealand 7 (Crosbie, 2006) to teach a topic about water access in sub-Saharan Africa. This complemented other material about water issues in South America and New Zealand. Following the topic, the teacher gave the students the option of undertaking a form of social action, to help alleviate the material poverty that people in the sub-Sahara suffered from. Actions were mostly around fundraising for certain NGO projects. Involvement was not formally assessed and it was not part of the achievement objectives, but the students were assessed on what they saw as the effects of the chosen social action in a formal essay. In this extract from the interview with the teacher, the teacher's dilemma of trying to impart a sense of empathy and willingness to take action among her students comes through:

$\mathrm{T}:[. .$.$] and there are some kids who are like, let's get out and let's do something about it and others$ who will talk and they'll write a whole page about all the things they're gonna do but they're not actually going to do anything,

RT: Why would that be...would that be a lack of engagement? A sort of disconnect?

T: Yeah ... It's ... a 'they', 'they' should do something, people should do rather than I could do. So it's that lack of connecting it to themselves ... but ... we work on that. [...] and we've written about it and l've said, well you've talked about how you feel sorry and people should go and do stuff but what l've asked you is what did you do. I ask the students 'What did you actually do and how are you helping, and what is your effort?' So trying to separate pity and empathy is a big thing. 
Activism - some kids have it, some kids don't. We try and foster it. But you know, some kids didn't... [emphasis by the teacher]

The teacher acknowledges that fostering activism is difficult to enact in the classroom. The action that they eventually choose is a class-collective child sponsorship deal through World Vision which, as she reflects further on in the interview, finds a mixed response:

T: And they've raised money for that child and they've written letters...we just did that yesterday actually ... so that's [it] again. The attempting ... and some kids want to write a letter, want to send photos, want to be involved, want to do more, and other kids are kind of like 'Oh well, we did something...we can move on now and not worry about that, cause we've solved that problem.'

She is very aware that in evaluating the learning of this social action, for some students it did not become an ingrained part of their lives, perhaps in comparison with other positive social behaviours taught at school, such as recycling, anti-bullying, buying ethical products etc. For some, the child sponsorship social action was just part of 'school'. It generated a 'tick-box' response. Further on in the interview, when asked if she had noticed any gender differences in the attitudes of the students, she remarks that the girls were more interested, while some of the boys actually asked 'if they can get NCEA ${ }^{8}$ credits for the letter-writing'. She is aware that the motivations for the letter writing activity differ across the class, and this ' what's in it for me?' attitude was an unwelcome outcome. In later personal communication ${ }^{9}$ she states that the students are sometimes not interested or too busy to take on this extra involvement, but she does not pursue their reasons. In a sense, she hopes that they will be inclined towards the social action, but acknowledges that not all of them will be.

She also notes that although she directs them towards a particular type of social action, she finds it difficult to leave the decision completely open to the students:

$\mathrm{T}$ : I think the key challenge for me is to not push my opinions ... [...] ... on to them. And that's quite difficult because I do have firm ideas and things and it's quite difficult to do a topic like l've just done and that's like I really want them to do something with World Vision because they have a great system set up to ... [...] ... whether it be pay for a child to go to school or give them a chicken ... or whatever, it's easy and it's quite ... you know ... and it's hard for me to sit back and say ... you guys come up with your own ideas without influencing them at all.

One of the key findings in the interview with the teacher was her reaction to dissenting questions concerning NGOs by the students:

T: And there's also ... I'm aware and I don't teach it, but l'm aware there's some political criticism with some NGOs coming in and ... not... and trying to enforce their own cultural values ... on a ... village ... um ... you know ... 'we want to educate the kids in this way ... for something...'

RT: Oh. ok,

T: It's not necessarily what the village needs or what the people need, it's what people perceive it's what they need.

RT: Yeah, 
T: But that's far too high level for these kids.

For this comment here by the teacher, I am not sure if critique of NGO activity was too difficult for the students, as in the focus groups they had many criticisms of their $\mathrm{own}^{10}$, but rather it may be that any discussion or critique may cause a questioning of the NGO, the suggested action and by implication, the teacher's pedagogy. Towards the end of the interview, the teacher does say that the students do ask critical questions and she follows these up:

$\mathrm{T}:[. .$.$] But the kids do sort of say ... 'oh but if I give my money you know, how much of that is used$ in administration and stuff', so we'll go and check this type of thing out.

RT: Right...

T: And I have been honest with them and said, look I don't know if your money for World Vision is better than going to Red Cross or any of those other agencies, I just know that it's easy.

From the interview I concluded that the teacher prescribed to Andreotti's framework of a 'soft approach' to global education, but was aware that this framework was not perfect. In personal correspondence, she identifies that her hope is to make the students more globally aware that their actions or inactions can have an impact on others and that as educators we cannot provide the answers, but should encourage the students to ask the questions. The NGO material was, in the teacher's own words, 'easy to use' and questioning its imperative concerning social action was seen as counter-productive. There was a strong ethical imperative to shift the students to care; anything less implied a danger of possibly leading to a form of moral apathy or paralysis, a difficulty Jefferess has encountered in his work with teachers (Jefferess, 2012). This non-action is something which Andreotti (2007) notes that radical or critical approaches, that raise the political and difficult questions, have issues with; knowledge without action can seem incomplete.

The World Vision resource used by the teacher is not a comprehensive historical, cultural or geographic account of Niger, this is not its intention. It is not compiled by Niger locals for students in New Zealand. It is focused on the significance of water for the people of the region, and in the booklet provided for the students, this is done by highlighting the physical aspects of the environment and how two people, a young girl and a woman work to obtain water access for daily use. Their daily routines and values towards water are compared with those of people in New Zealand who may view water as an infinite resource. Towards the end of the resource, various NGOs and their initiatives in the area are profiled. Many have a connection to World Vision. There is no direct call to sponsor an initiative with World Vision, although it is present as a suggestion. The resource is positive in its general outlook and the Niger people profiled are not shown as needy or pitiful, waiting for Western help.

Evaluating such a course of action is problematic, because it is important to evaluate separately the intent from outcome. What did the students really learn 
about poverty, the Other, themselves, the NGO industry and what constitutes social justice? The learning outcomes were more than increased knowledge or awareness: the emphasis had been on action, on assistance, on something tangible that could bring about a morally uplifting closure to the topic. Regarding voluntary social action by students, Brooks (2007) has identified that there are mixed motivations for undertaking voluntary social action, such as wanting to learn about community work, being in a community, adding the experience to the $\mathrm{CV}$ and political reasons for engagement. If this is the case for voluntary work, what are the motivations and the outcomes in terms of learning when social action is semi-obligatory? The difficulty is trying to fully understand what the actual learning outcomes are, when social action of a global charitable nature is part of the learning about the distant Other, an issue raised in the literature as discussed above. In this classroom, the range of attitudes is apparent, with some students expressing a real interest in the child sponsorship action (during the student focus group activities, one female student asks how old one has to be in order to start sponsoring a child, because she genuinely wishes to do so), and at the other extreme, those boys for whom the action was only worthwhile if it contributed to their educational progress.

If the expected emotions are not forthcoming or are inauthentic, the real learning that takes place may be quite oppositional to the intended outcomes. One concern is that for some students, if forced (not literally, but morally) to carry out a certain type of 'sanctioned social action' that does not fit with them personally, what does the distant Other become to them? A nuisance, a pain, or something remote that flickers on the scene for a short time, then is easily removed through social acts that require a little (but not too much) personal sacrifice? The lasting impression of the Other may be quite removed from an empathic engagement.

Through the images and the text, often supplied by an NGO, a teacher may hope and plan for a breakthrough in the classroom, towards a transformative emotive moment in which students move beyond their world to try to feel the world of the Other. Returning to Todd, she posits that there exists a tension within education, in that reality is silent next to idealism. We strive to make the world a better place, and we encourage our students to look towards those aspects of our humanity that are intrinsically good, like tolerance, compassion and justice. What is marginalised is that ugly side of our humanity. Todd raises this issue in her first chapter:

...in educating for humanity, we run the risk of creating for children a world which does not respond to it as it is, and create instead a harmonious image of what we adults want the world to be. (Todd, 2009:16, her emphasis)

This seeking of idealism is built upon hope, and teaching for social justice would seem to be just words without action, so how do we proceed? Facing the student's reality is difficult and unpredictable and yet, if we do not, we may be denying them 
room to speak, and placing a great burden upon their shoulders, a burden which they may seek to evade. Ignoring cynical attitudes or a lack of compassion may have unintentional outcomes.

\section{The centrality of the student: what did I learn, how did I feel?}

With regards to the centrality of the student, in terms of how they are positioned, with these students the solidarity with the Other was expressed through a tactile activity which involved carrying a bucket of water on their heads, to appreciate what the Other experiences, to attempt to walk in their shoes. In this exchange, at the beginning of the focus group activity, these three students are describing the topic, which they had recently completed:

A: The topic was about water wars and how people had to...people had to struggle to get water...

B: where we live in the city where it's...

A: and we were fundraising money for...

B: and we don't have to walk 200 metres or 200 kilometres or 200 miles....

The next question asks them what their overall impressions were of the people and the place from the topic:

A:Yeah, we learned about Niger and pretty much you have to walk like three ks just to get a bucket of water

B: Five metres or something

A: That wouldn't be everyone...that was just that specific person

C: And we sponsored a child...

A: and then we had to do a test to see how long it would take us to get water from a certain spot, didn't we? We went out with a bucket carried on our heads...

B: yeah...

C: cool topic anyway

The impressions are of the deficit of the Other and then a sense of pity which leads to 'our' ability to assist. The fundraising and sponsoring is part of the location. The exaggeration of the distances to retrieve water cause the students to debate the distances as the situation of the Other borders on becoming 'ridiculous' in their memory of it. Although they may have learnt about historical and contextual causes for inequality, their brief remembrance of the topic in this study excludes this and deeper reflection about their own country or personal role is absent (Boler, 1999; Britzman, 1997). It was a 'cool topic', with closure. Finally, there was a lack of agency on behalf of the Other; inasmuch as they are solely remembered and represented by a grateful child, a small picture of whom is on the classroom wall. Any dissenting political voices, the voices of adults, particularly those in leadership, are absent. The lack of critical Southern voices in NGO material has been discussed in the literature 
(Gallwey, 2010; Graves, 2007; Murphy, 2011; RORG, 2004). It is unlikely that these are the impressions the teacher, nor the NGO, were hoping the students would be left with, but they illustrate the pedagogical difficulty of teaching about the distant and vulnerable Other.

\section{Murmurings of dissent}

Within the classroom, NGO material sometimes carries a strong ethical imperative, but some students bristle and do not always accept the intended messages nor the emotive demands. In this research the methodology allowed the students, through their self-moderated discussions, to freely express what they thought of NGO messages about the South. One of the questions in the focus group activity asks the students their opinion of the 'typical NGO poster that you might see around school'. A stylised graphic of a small child with accompanying text 'donate now and make a difference' is shown as an example. The students comment that they are familiar with this type of poster. In this revealing exchange between two boys from the same classroom mentioned above, there is a rift in the emotional account:

Boy A: So ... I think that they need help.

Boy B: Yeah ... um ... to be honest, I actually kind of laugh [laughs]

Boy A: Well, that's ... that's quite mean ... shame

Boy B: Well ... it kind of ... it doesn't seem that sad when they're all happy and stuff you know ... I guess when it's a photo of them all sad and that ... probably

Boy A: But you know ... that is a photo of them sad until or like you give them something and they're like, real happy and so when they take the photo it's like 'be sad!'

Boy B: yeah...

Boy A: make us Africos real sad or demented since people'll make you look good.

Boy B is not afraid to honestly state that he laughs at the image and mocks the NGO appeal outright. He knows he is meant to feel a certain way, but he does not and he honestly states that. Significantly, he is chastised by his peer, who says that is mean, shame on him, he has transgressed the line of decency. The boys then change their stance and at the end they are critical of the 'staged look'. On the recording, Boy A lowers his voice and says the sentence 'make us Africos...' quickly with a strong mocking tone, knowing it is dissenting. They have repositioned themselves into critics of the NGO marketing, which allows them the space to negate those required feelings of empathy and voice their scepticism (Seu, 2010). It is unlikely that they would have voiced these opinions with the teacher present, and this frank exchange reveals the possibility that discontent and scepticism may lie beneath the surface affirming other findings (Dalton, et al, 2008; Hibbert, et al, 2007). It illustrates that some students are not passive, affirmative receivers of NGO messages: they have their own thoughts. 
It should be noted that this paper is focusing on concerns raised by certain tropes within the dialogues recorded by the activities. For this discussion, exchanges that illustrate the issues have been chosen, but this does not mean that these were representative of the whole class. There were also exchanges amongst the students that revealed (some) awareness of contextual reasons for poverty, such as colonialism and trade inequalities, as well as positive feelings, such as admiration for the resilience of people of the global South. The intent in highlighting the more worrying accounts is to show that there is a range of motivations, emotions and learning outcomes around teaching about the distant Other in the classroom.

\section{Concluding comments}

The two concerns that this paper raises, the use of emotion in development education that employs a 'soft approach'; and the centrality of the student when considering Others, have been raised in the literature previously as noted. Many commentators call for more empirical evidence of how these issues play out in reality. The evidence given here of one particular context is not designed to be conclusive, nor representative, but illustrative of the difficulties that one teacher faced in teaching about the Other and including social action as part of the topic. Sinclair (1994:55) identified three different relationships that NGOs have with schools and teachers: input into curriculum activities, such as visiting speakers; extra curricula activities, such as fundraising events; and finally, opportunities for teachers to resource and develop the curriculum. For the first two, Sinclair has reservations that they have limits and can have a negative impact. For the final relationship he does not give such a condition.

From the evidence presented in this paper I would extend Sinclair's comment that if NGO material is featured in the classroom, it needs to be fully evaluated for both its perspective on development and its learning outcomes. Even if material is well structured to fit the curriculum, and easy to use, at worst it could be narrow, oversimplified and pedagogically unsound, with educational consequences. These can include a closing down of other ways of thinking about development, increased ethnocentrism, and a deficit approach to learning about the global South. One of the key critiques of this 'soft' framework is that learning is about the Other not with or from the Other (Jefferess, 2008). The examples from this research have shown how emotions, position, pedagogy and learning outcomes are all interlinked and significant in the space of learning where NGO material interacts with the curriculum. The issues of representation, social action and learning are complex, not well mapped and deserve greater attention.

The author would like to thank Dr Joanna Kidman, Victoria University of Wellington; Dr Steve Tallon; and the two anonymous reviewers, for their feedback on earlier drafts of this paper. 


\section{Notes}

1 This term is used to describe the people or cultures that are often materially less well-off and culturally or geographically distant from the student who is studying them.

2 Previously known as the Development Resource Centre, it was renamed Global Focus Aotearoa in 2010.

3 The National Government, elected in 2008, restructured the main overseas agency, NZAID.

4 Equivalent to year 9 in the UK system.

5 This learning area encompasses the four core subjects of history, geography, social studies and economics at senior level, while at junior level they are grouped together in a subject called social studies.

6 Several images were supplied by NGOs interested in this research.

7 World Vision is a prominent resource provider for schools in New Zealand.

8 National Certificate in Education Achievement.

9 The interview was followed up with further questions via email.

10 The students, like students in the other schools in the study, were sceptical of where and how NGO funding was spent, the role of celebrities in promoting causes and the 'staged' photos of NGO campaigns. They did not have a rosy, wholly positive view of NGOs.

Rachel Tallon is a doctoral candidate in Development Studies at the School of Geography, Environment and Earth Sciences, Victoria University of Wellington, New Zealand. She is a trained secondary school teacher of the social sciences and prior to studying was an education officer for a New Zealand NGO.

\section{References}

Anderson, K. and Smith, S. (2001) Editorial: emotional geographies. Transactions of the Institute of British Geographers 26(1) p. 7-10.

Andreotti, V. (2006) The contributions of post-colonial theory to development education. DEA Thinkpiece, 12 , London, DEA.

Andreotti, V. (2007) An Ethical Engagement with the Other: Spivak's ideas on Education. Critical Literacy: Theories and Practices 1(1) p. 69-80.

Andreotti, V. (2010) Postcolonial and post-critical 'global citizenship education'. In G. Elliot, C. Fourali and S. Issler (eds.) Education and Social Change: Connecting local and global perspectives. London: Continuum.

Arnold, S. (1988) Constrained Crusaders? British Charities and Development Education. Development Policy Review 6, p. 183-209.

Beals, F. (2009) Global Education: Transforming the world through community education. Global Perspectives $1 \mathrm{p}$. 4-5.

Biccum, A.R. (2005) Development and the 'new' imperialism: a reinvention of colonial discourse in DFID promotional literature. Third World Quarterly, 26(6) p. 1005-1020.

Biccum, A.R. (2007) Marketing Development: Live 8 and the Production of the global Citizen. Development and Change, 38(6) p. 1111-1126.

Boler, M. (1999) Feeling Power: Emotion and Education. New York: Routledge.

Boltanski, L. (1999) Distant Suffering: Morality, Media and Politics (G. Burchell, Trans.). Cambridge: Cambridge University Press.

Bourn, D. (2011) Discourses and Practices around Development Education: From Learning about Development to Critical Global Pedagogy. Policy and Practice - A Development Education Review, 13(Autumn) p. 11-29.

Britzman, D. P. (1997) The tangles of implication. Qualitative Studies in Education, 10(1) p. 31-37.

Brooks, R. (2007) Young People's Extra-Curricular Activities: Critical Social Engagement - Or 'Something for the CV?'. Journal of Social Policy, 36(3) p. 417-434.

Bryan, A. (2011) Another Cog in the Anti-Politics Machine? The 'De-Clawing' of Development Education. Policy and Practice - A Development Education Review (12) p. 1-14.

Bryan, A. and Bracken, M. (2011) Learning to Read the World? Teaching and Learning about Global Citizenship and International Development in Post-Primary Schools. Dublin: Irish Aid.

Chouliaraki, L. (2010) Post-humanitarianism: Humanitarian communication beyond a politics of pity. International Journal of Cultural Studies, 13(2) p. 107-126.

20 International Journal of Development Education and Global Learning 4(2) 2012 
Chouliaraki, L. (2011) 'Improper distance': Towards a critical account of solidarity as irony. International Journal of Cultural Studies, 14(4) p. 363-381.

Cohen, S. (2001) States of Denial: Knowing About Atrocities and Suffering. Cambridge: Blackwell Publishing.

Crosbie, S. (2006) Water Wise. Auckland: World Vision.

Crush, J. (1995) The Power of Development. New York: Routledge.

Dalton, S., Madden, H., Chamberlain, K., Carr, S. and Lyons, A. C. (2008) 'It's Gottena Bit Old, Charity': Young Adults in New Zealand Talk About Poverty, Charitable Giving and Aid Appeals. Journal of Community and Applied Social Psychology, 18 p. 492-504.

Davidson, J. and Milligan, C. (2004) Embodying emotion sensing place: introducing emotional geographies. Social and Cultural Geography, 5(4) p. 523-532.

den Heyer, K. (2009) Implicated and called upon: Challenging an educated position of self, others, knowledge and knowing as things to acquire. Critical Literacy: Theories and Practices, 3(1) p. 26-35.

Department for International Development (DFID) (2002) Making Sense of the World: A joint BBC News - DFID study of public perceptions of television news coverage of developing countries: Department for International Development.

Diprose, G. (2003) Imagining Development. Unpublished Dissertation, University of Otago, Dunedin.

Escobar, A. (1994) Encountering Development: The Making and Unmaking of the Third World: Princeton University Press.

Gallwey, S. (2010) The role of Southern perspectives in the evaluation of development education. [online]. Policy and Practice - A Development Education Review (11) p. 69-76.

Graves, J. (2007) The changing landscape of development education. Policy and Practice - A Development Education Review (5) p. 86-91.

Hibbert, S., Smith, A., Davies, A. and Ireland, F. (2007) Guilt Appeals: Persuasion knowledge and charitable giving. Psychology and Marketing 24(8) p. 723-742.

Jefferess, D. (2008) Global citizenship and the cultural politics of benevolence. Critical Literacy: Theories and Practices 2(1) p. 27-36.

Jefferess, D. (2012) The 'Me to We' social enterprise: Global education as lifestyle brand. Critical Literacy: Theories and Practices, 6(1) p. 18-30.

Joffe, H. (2008) The Power of Visual Material: Persuasion, Emotion and Identification. Diogenes 217 p. 84-93.

Kapoor, I. (2004) Hyper-self-reflexive development? Spivak on representing the Third World 'Other'. Third World Quarterly 25(4) p. 627-647.

Kenway, J. and Youdell, D. (2011) The emotional geographies of education: Beginning a conversation. Emotion, Space and Society 4, 131-136.

Lambert, D. and Morgan, J. (2011) Geography and Development: Development education in schools and the part played by geography teachers. London: Development Education Research Centre: Institute of Education, University of London.

Lidchi, H. (1993) All in the Choosing Eye: Charity Representation and the Developing World. London: Open University.

Lindquist, J. (2004) Class Affects, Classroom Affectations: Working through the Paradoxes of Strategic Empathy. College English 67(2) p. 187-209.

Manzo, K. (2006) An Extension of Colonialism? Development education, images and the media. The Development Education Journal 12(2) p. 9-12.

Marshall, H. (2005) Developing The Global Gaze in Citizenship Education: Exploring the Perspectives of Global Education NGO Workers in England. International Journal of Citizenship and Teacher Education 1(2) p. 76-92.

Ministry of Education (2007) The New Zealand Curriculum. Wellington: Learning Media Limited.

Moeller, S. (1999) Compassion Fatigue: How the Media Sell Disease, Famine, War and Death. New York Routledge.

Mohanty, C. (1988) Under Western Eyes: Feminist Scholarship and Colonial Discourses. Feminist Review 30 p. 61 88.

Murphy, C. (2011) Challenges and Considerations for Embedding an African Perspective in Development Education. Policy and Practice - A Development Education Review 13(Autumn) p. 49-61.

Osler, A. (1994) Development Education: Global perspectives in the curriculum. London: Cassell. 
Overton, J. (2009) Reshaping Development Aid: Implications for Political and Economic Relationships. Policy Quarterly 5(3) p. 3-9.

Paech, M. (2004) A Photograph is Worth More Than a Thousand Words: The Impact of Photojournalism on Charitable Giving. Master's Thesis, SOAS. University of London

Pykett, J., Cloke, P., Barnett, C., Clarke, N. and Malpass, A. (2010) Learning to be global citizens: the rationalities of fair-trade education. Environment and Planning D: Society and Space 28(3) p. 487-508.

Radley, A. and Kennedy, M. (1995) Charitable Giving by Individuals: A Study of Attitudes and Practice. Human Relations 48(6) p. 685-709.

Rajacic, A., Surian, A., Fricke, H.-J., Krause, J. and Davis, P. (2010) Study on the Experience and Actions of the Main European Actors Active in the Field of Development Education and Awareness Raising - Interim Report. Brussels: European Commission.

Roman, L. (2003) Education and the contested meanings of 'Global Citizenship'. Journal of Educational Change 4 p. $269-293$.

RORG. (2004) Southern Perspectives and Co-operation with the South. Olso, Norway: RORG Network.

Seu, B. (2010) 'Doing denial': audience reaction to human rights appeals. Discourse and Society 21(4) p. 438-457. Silverstone, R. (2007) Media and Morality: on the rise of the mediapolis. Cambridge: Polity.

Sinclair, S. (1994) Introducing Development Education to Schools: The Role of Non-governmental Organizations in the United Kingdom. In A. Osler (ed.) Development Education: Global Perspectives in the curriculum. London: Cassell.

Small, D. (1997) Development Education Revisited: The New Zealand Experience. International Review of Education 43(5-6) p. 581-594.

Smith, M. (1999) Teaching the 'Third World': unsettling discourses of difference in the school curriculum. Oxford Review of Education 25(4) p. 485-499.

Smith, M. (2004) Contradiction and change? NGOs, schools and the public faces of development. Journal of International Development 16(5) p. 741-749.

Smith, M. (2008) International non-governmental development organisations and their Northern constituencies: development education, dialogue and democracy. Journal of Global Ethics, 4(1) p. 5-18.

Smith, M. and Yanacopulos, H. (2004) The Public Faces of Development: An Introduction. Journal of International Development 16, p. 657-664.

Standish, A. (2009) Global Perspectives in the Geography Curriculum: Reviewing the moral case for geography. London: Routledge.

Tallon, R. (2011) Creating 'little sultans' in the social sciences: learning about the other through benevolent eyes. International Research in Geographical and Environmental Education 20(4) p. 281-286.

Taylor, L. (2011) Beyond Paternalism: Global Education with Preservice Teachers as a Practice of Implication. In V. Andreotti and L. M. De Souza (eds.) Postcolonial Perspectives on Global Citizenship Education (p. 177-199). Abingdon: Routledge.

Todd, S. (2003) Learning from the other; Levinas, psychoanalysis and ethical possibilities in education. Albany: State University of New York Press.

Todd, S. (2009) Towards an Imperfect Education: Facing Humanity, Rethinking Cosmopolitanism. Boulder, CO: Paradigm Publishers.

Vestergaard, A. (2008) Humanitarian branding and the media: The case of Amnesty. International. Journal of Language and Politics 7(3) p. 471-493.

VSO. (2002) The Live Aid Legacy: Volunteer Service Overseas. 